\title{
Bilimkurgu Sinemasında Bașka Gezegenlere Göç: Beden, Kimlik ve Benlik Kavramları Çerçevesinde “Pandorum” Filmi Üzerine Bir İnceleme
}

\author{
Mikail BOZ1
}

\begin{abstract}
Öz
Göç olgusu Dünya gezegeni üzerindeki insan hareketlerini nitelendirse de artan nüfusun gereksinimlerini karşılayacak kaynakların kıtlığı, küresel ısınma, biyolojik felaketler olasılığı, dünya dışı yaşamlarla karşılaşma ve yapay zekâya dönük endişeler göç süreçlerini daha evrensel düzeyde, yakın geleceği gözeten boyutta değerlendirmeyi gerekli kılmaktadır. Yirminci yüzyılın başından itibaren galaktik boyutta göçe imkân verecek olan nesil yıldız gemileri (generation starship) düşünülmeye başlanmış ve bu tür bir yolculukta hangi sorunların yaşanabileceği gündeme taşınmıştır. Bu yolculuğun ilk örneklerini ise bilimkurgu sinemasında görmek mümkündür.

Bu çalışmada insanlığın başka bir gezegene yolculuğunu ve kolonileştirmeyi başlangıçta bir istençli göç, sonrasında ise zorunlu bir mültecilik olarak ele alan Pandorum (Christian Alvart, 2009) filmi, nitel yaklaşımla tematik ve betimsel anlatı analizine tabii tutulmuştur. Analize kavramsal arka plan sağlaması açısından göç, bilimkurgu ve nesil yıldız gemileri, beden sosyolojisi, benlik, kimlik ve öteki kavramları tanımlanmıştır. Filmin insanlığın galaktik boyuttaki göçünü nasıl ele aldığı, bu göçün mültecilerin insanlığını nasıl etkilediği, göçün uygarlık değerlerinin nasıl aşındırabileceği ve ne türden tehlikeler içerdiği, J.D. Bernal'in literatürdeki öncü çalışmasının metaforik başlıkları olan "dünya", "beden" ve "şeytan" kavramları etrafında, anlatı analiziyle ortaya konmuştur.
\end{abstract}

Anahtar Kavramlar: Galaktik göç, bilimkurgu sineması, beden, kimlik, benlik, nesil yıldız gemisi, Pandorum, Christian Alvart.

Atıf: Boz, M. (2020). Bilimkurgu Sinemasında Bașka Gezegenlere Göç:

Beden, Kimlik ve Benlik Kavramları Cerçevesinde "Pandorum” Filmi Üzerine Bir İnceleme. Akdeniz Üniversitesi İletișim Fakültesi Dergisi, 33, s. 275-295

1 Dr. Öğr. Üyesi, Bozok Üniversitesi, İletişim Fakültesi, Radyo Televizyon ve Sinema Bölümü. bozmikail@gmail.com, ORCID Numarası: 0000-0003-4276-1521. 


\title{
Migration to 0ther Planets in Science Fiction Cinema: A Study on "Pandorum" within the Concepts of Body, Identity and Self
}

\begin{abstract}
Though the immigration characterizes human movements on the planet Earth, it is necessary to evaluate it with universal perspective, and the near future risks, such as the shortage of resources, global warming, biological disaster possibilities, encounter with extraterrestrial life, and concerns of artificial intelligence. The migration of humanity to other planets or habitats, which seems to be as "science fiction" from today, stands out as a "fate" in which humanity will eventually be confronted. Such a theme is the subject of both scientific research and fictional works. Transportation to the nearest star systems requires a great deal of time and effort. This makes it possible to assess the role of humanity to create another habitat in space, both in terms of migration and the concept of refugees when possible risks are taken into consideration. From the beginning of the twentieth century, the generation starship, which would allow migration to the galactic level, were considered and brought to the agenda what problems could occur on such a journey. It is possible to see the first examples of this journey in science fiction cinema.

In this study, the film Pandorum (Christian Alvart, 2009), which initially considered the humanity's the journey to another planet and colonization it as a semi-voluntary migration, was subjected to thematic and descriptive narrative analysis with a qualitative approach. In terms of providing conceptual background to analysis, migration, science fiction and generation starships, body sociology, self, identity and other concepts are defined. It has been revealed how the film deals with the galactic migration of humanity, how it affects to human condition the being a refugee, how the civilization values can be eroded and what kind of dangers it poses, with narrative analysis around the metaphoric concepts of J.D. D. Bernal's pioneering work in the literature "the world", "the flesh," and "the devil".
\end{abstract}

Keywords: Galactic migration, science fiction cinema, body, identity, self, generation starship, Pandorum, Christian Alvart.

\section{Giriș}

nsanlığın tarih boyunca mekânlar arasında hareket ettiğini, oldukça uzun bir süre göçebe bir yaşamı benimsediğini söylemek mümkündür. Yaşanılan mekân bir şekilde gereksinim ve arzulara cevap vermediğinde farklı coğrafya ya da ekosistemlere göçen insan, farklılaşan coğrafyaya uyum sağlamak için kendisini de farklılaştırmıştır. Yerleşik yaşama geçiş uygarlığın yükselişinde temel dinamik olsa da tarih boyunca büyük göç hareketleri gerçekleşmiş ve gerçekleşmeye devam etmektedir. Mültecilik ve göçmenlik durumu öteden beri yerleşik hayat süren insanlar için hep bir başkasına, "ötekine" ait bir nitelik gibi görünmektedir. Şenel'e göre, neolitik tarım devrimiyle birlikte yerleşik hayata geçmeye çalışan insanlık kendini ve çevresini sürekli dönüştürmekte, 
yeniden üretmektedir. Bu yerleşik kültür kendini kurumlaştırırken sürekli istilacılarla ve davetsiz misafirlerle karşılaşmaktadır. İçinde bulunduğu mekânı korumaya çalışırken de erzaklarını ve kimliğini istilacılardan koruma uğraşı vermekte, "ulusal" kimliğini inşa etmekte ve toprak bir "yurt" anlamını taşımaya başlamaktadır (2006, ss. 265-269). Modern dönemde de savaş gibi birincil nedenler kitlesel göçleri ivmelendirmiştir. Ekonomik geri kalmışlık, deprem ve sel gibi felaketler ya da belirli bir topluluğa dönük soykırıma varan müdahaleler de göçü etkileyen diğer etkenlerdir. Bununla birlikte göçmenlik ve mültecilik durumunun gelecekte, dünyadan toplu bir göç zorunluluğu olarak ele alındığında insanlığı beklediğini çıkarsamak mümkündür. Güneş’in yakıtını tüketmeye (mass loss) başlaması tüm gezegenlerin yapısını değiştirecektir. Hafif hidrojen ve helyum atomlarından sonra daha ağır elementleri yakmaya başlayan Güneş giderek şişip bir "kızıl dev" halini alacaktır. Merkür ve Venüs'ün ardından sıra Dünya'ya gelecek, yaklaşık dört milyar yıl sonra Dünya, Güneş'in içyapısına katılacaktır. Bir milyar yıllık süre sonraysa Güneş patlayıp, kendi içine çökerek bir beyaz cüceye dönüşecektir (Schröder ve Smith, 2008). Bilimsel çalışmaların ortaya koyduğu bu son, insanlığın başka dünyalara, yıldız sistemlerine göç etmesini varoluşu açısından bir zorunluluk olarak ortaya koymaktadır.

Ortaya konulan bu durum oldukça uzak bir geleceğe gönderimde bulunmaktadır. Bununla birlikte İkinci Dünya Savaşı sonunda, 6 ve 9 Ağustos 1945’te, ABD’nin Japonya'nın Hiroşima ve Nagasaki kentlerine atom bombası atması ve sonrasında ortaya çıkan "Soğuk Savaş", genel bir felaket ve sonun insan eliyle ve teknolojik yeteneğiyle ${ }^{2}$ geleceği düşüncesinin belirmesine yol açmıştır. Daha büyük bir savaşın ortaya çıkmasındaki engelleyici şeyin toptan bir yok oluş korkusu olduğu "dehşet dengesi"nde (Mutual Assured Destruction) (Project of the Nuclear Age Peace Foundation, 2018), modern insan her sabaha bir "son sabah" gibi uyanma kaygısıyla başa çıkmak durumunda kalmıştır. Yok oluşa dönük kaygının önemli bir ifadesi ilk defa 1947 yılında Atom Bilimcileri Bülteni (BPA) tarafından oluşturulan ve "Kıyamet Saati" olarak bilinen saattir. Kıyameti sembolize eden "gece yarısı"na ne kadar zaman kaldığını gösteren bu saat, 25 Ocak 2018 tarihinde 30 saniye ileri alınmıştır. Bu ileri alma ile birlikte insanlığın yok olmasına sadece "2 dakika" kalırken 29 Ocak 2020 tarihindeki güncelleme ile süre yirmi saniye daha kısalmış, kıyamete bir dakika kırk saniye kalmıştır (Bulletin of the Atomic Scientists, 2020). Küresel ısınma, yapay zekâ ve robot teknolojisinin getirdiği olası riskler, viral salgın, dünya dışı yaşam formlarıyla temas, su gibi stratejik kaynaklar üzerindeki uzlaşmazlıklar ve bölgesel ve genel savaş riski geleceğe dair endişeleri sürekli artırmaktadır (Boz, 2018, s. iv). Dolayısıyla bu endişeleri hem görünür kılacak hem de onlarla başa çıkma imkânı verecek çeşitli türde sanat eserlerinin ortaya çıkması normaldir.

Belirli türden bir kıyameti ya da kıyamet sonrası durumu ele alan filmlerin üretim miktarına bakıldığında (Bkz., Boz, 2018), geleceğe dair korkuların yükselişinde bir ivmelenmeyi tespit etmek mümkündür. Bilimkurgu sineması, içine korku ve fantastik öğeleri de harmanlayarak geleceği imgelemeye başlamış, bugünün insanlarının torunlarını, yani yarının mültecilerini başka dünyalara göçerken anlatmıştır. Dolayısıyla geleceği imgelemeye dönük temsillerin incelenmesi, bunlar yoluyla hangi türde arzu ve korkuların 
görünür olduğunu anlamak gerekmektedir. Bu çalışmada da Christian Alvart'ın yönettiği Pandorum (2009) filmi örneği üzerinden başka dünyalara göçün getirdiği zorluklar ve bunun insanlık üzerindeki yarattığı etkiler analiz edilmiştir.

\section{Amaç, Yöntem ve Örneklem}

Bu çalışmanın amacı bir bilimkurgu filmi üzerinden başka dünyalara göç konusunun sorunsallaştırılma biçimini anlamaya çalışmaktır. Göç konusunun güncelliği ve evrenselliği gözetildiğinde, bilimkurgu sinemasındaki spesifik filmlerin bu soruna nasıl yaklaştığı, hangi türden tehditleri belirleyip ne türden çözümler sunduğunu anlamaya çaIışmak belirli türde korkuların ve çözümlerin temsil edilişini anlama konusunda önemli bir perspektif sunmaktadır. Pandorum filmi, Almanya, Birleşik Krallık ve ABD ortaklığında çekilen ortak yapım bir filmdir. Yıldızlararası göç konusunu ele alan pek çok film olsa da amaçlı örneklem olarak Pandorum filminin seçilmesinde, filmin, aşağıda sıralanan yöntemin ana başlıklarıyla uyumlu bir şekilde, süreci bedenin transformasyonu, dönüşümü eksenine yerleştirmiş olması, dolayısıyla ben/öteki gibi ayrımlar konusunda çözümleme için zengin bir malzeme sunmasıdır.

J. D. Bernal yıldızlararası yolculuklar ve göç üzerinde çalışmalar yapan ilk bir bilim insanlarından birisidir. Bernal, "The World, The Flesh, and The Devil" adlı 1929 tarihli çalışmasında, nesil yıldız gemileri ve uzay yolculukları konusunda, sistematize edilmiş öngörüler ortaya koymuştur. Bernal çalışmasında bu tür yolculuklara temel olacak teknik gelişmeler, yolculuk için yapılması gerekenler, bu yolculuğun yaratacağı risk ve fırsatlar konusunda bilimsel öngörüler sunmuştur. Bu çalışmada da yöntem olarak Bernal'in klasik eserindeki yöntemsel başlıklar kullanılmıştır. Bunlar vasıtasıyla şu tür sorulara cevap aranmıştır: Filmde başka dünyalara göç öncesinde betimlenen dünyanın durumu nedir? Bu yolculuk esnasında insan beden, kimlik ve benliğinde ne tür değişimler gerçekleşmiştir? Yolculuk esnasında karşılaşılan tehdit ve riskler nelerdir? Bunlara karşı önerilen bir sentez, çözüm önerisi var mıdır, varsa nedir?

Bernal'e göre (1929, B.I, p.1) insanlığı bekleyen "iki tür gelecek vardır. Arzu edilen gelecek ve kader olan gelecek. İnsanın aklı ikisi arasında hiçbir zaman ayrım yapamamıştır". Bernal metaforik "dünya", "beden" ve "şeytan" başlıkları altında, insanların başka dünyalara göçü ve hem göç aracı olan gemileri, "nesil gemilerini”, hem de bu dünyaların transformasyonu hakkında düşüncelerini ortaya koymuştur. Bernal'in belirlediği ana başlıklar belirli durumları ifade etmek için metafor olarak görülebilmektedir.

- "Dünya”: Bernal (1929, B.II) bu başıık altında dünyadaki durumu değerlendirmiştir. Buna göre dünyada teknolojinin gelişmesi, uzaya açılma itkisi uyandıracak, zamanla burada kalıcı evler yapma imkânı doğacaktır. Dolayısıyla Bernal analize temel olacak biçimde belirli bir teknolojik yetkinliği şart koşmakta, bu yetkinliğin niteliği ve sonuçlarını tartışmaktadır. Bunun filmdeki karşılığı dünyadaki durumun betimlemesi, insanların böyle bir yolculuğa neden gereksinim duyduklarının ortaya konması yönündedir. Dolayısıyla yöntemsel olarak bu başlık maddi dünyanın, onun yarattı̆̆ı itkilerin betimlemesini sağlamaktadır.

• "Beden": Bernal bu başlık (1929, B.III) altında insanı bedeni çerçevesinde ele almıştır. Artık yeni çevreye gidilmesi veya çevre yaratılması bağlamında insan bedeni tartışma konusu haline gelmektedir. Bedenin mekanizasyonu süreci insanı çok farklı bir duruma sokarken, onu belli alanlarda uzmanlaşması yoluyla daha işlevsel bir bedensel yapının 
kurulması olanaklı hale gelmektedir. Bu durum bir yandan dışsal yani çevresel şartların zorunlu bir sonucudur. Diğer yandan mevcut şartlara uyum ve yeniden uyum temelde benlik, kimlik ve beden algısını tartışmaya açacak bir analitik malzeme sağlamaktadır. Böylece maddi dünyada yaşayan öznenin dönüşümü, öznenin kendisi tartışmaya açılmaktadır.

- "Şeytan": Bernal bu başlık (1929, B.IV) altında mistik anlamda bir "Şeytan'dan değil, bu yolculuğun getirdiği olası tehlikeleri ortaya koymaktadır. Ona göre yıldızlararası yolculuklarda insan psişesinin sınırlarını ortaya koyan bir "şeytan" bulunmaktadır ve bu tehdit ilk başta görünmemektedir. "Şeytan, uğraşmak için en zor olanıdır: o kendi içimizdedir, onu göremeyiz. Bizim kapasitelerimiz, arzularımız, iç karışıklıklarımız, şu anda anlamak ya da başa çıkmak için neredeyse imkânsızdır" (1929, B.4, p.1). Ona göre bu tehditlerle başa çıkmak çevreye uyum sağlayıp yeniden dengeyi sağlamak anlamına gelmekte ve çok yönlü riskler içermektedir. Dolayısıyla öteki olmaktan korkma, onu içselleştirme, ortaya çıkan bu "yeni" insanın ne olduğunu kavrama insanlığın geleceğine yön verici bir etkiye sahiptir. Böylece öznenin dönüşümü, onun kendisinden, kendi türünden ortaya çıkan "öteki" ile temasının analiz edilmesini sağlamaktadır.

- Sentez: Bernal'e göre (1929, B.V). artık yeni varlık durumunun, bunun arzu edilirliğinin kendisi tartışmalı hale gelmektedir. Bernal psikanalizin terimlerinden faydalanarak sınırsız bir natüralizmin ve Id'in baskın güç oluşunun, ya da sınırsız bir rasyonalitenin, süper-egonun baskın oluşunun getireceği risklere dikkat çekmektedir. Bir sentez gereklidir ve sonuçta arzulanan ve imgelenen gelecek yeni tipte bir insan yaratacak, bu insan da yeni arzulara sahip olacaktır. Gelişme ve yenilenmenin diyalektiği budur

Bernal'in insanlık durumu ve onun geleceği hakkındaki görüşleri aydınlanmacı ve Marksist bir gelenek içerisinde iyimser olarak nitelendirilebilmektedir. Ayrıca Bernal'in bu kavramsallaştırmasını sinema metinlerini de kapsayan genel anlatı şeması içerisine yerleştirmek mümkündür. Dolayısıyla Bernal'in kavramsallaştırması aynı zamanda bir anlatının betimsel genel çözümlemesi için analoji olarak görülebilir. Anlatı serimleme (exposition) yükselen eylem (rising action) doruk (climax) düşen eylem (falling action) ve akıbet (denouement) olarak, dramatik bir çerçeve sunmaktadır (Barsam, 2010, s. 119). Bernal de çalışmasında genel bir durum saptaması yaparak serimleme yapmakta, karşılaşılabilecek riskleri gözeterek çatışmanın doruk noktasına çıktığı yönleri ortaya koymakta, bir sentez ve akıbet belirlemeye çalışmaktadır. Bernal kendisinin de makalesinde yaptığı gibi, bu analiz psikanalizin ve sosyolojinin temel "beden", "kimlik", "ben ve öteki" gibi kavramlarını bir "alet çantası" olarak el altında tutmayı gerektirmektedir. Analizde bu perspektifle ilgili sosyolojik ve psikolojik kavramlardan da yararlanılmış, çözümlemede filmdeki ana motifi vurgulayacak çeşitli ara başlıklarla kategorik ayrım yapılmaya çalışılmıştır.

\section{Göc, Bilimkurgu Sineması ve Nesil Yııdız Gemileri}

Göç süreçlerine ilişkin ilk elde çıkarılacak bir sonuç, onun asla "yeni" bir şey olmadığıdır. İnsanlığın hemen bütün tarihi, temel düzeyde bir göç hareketidir. Homo sapiensin "Afrika'dan çıkış" hareketiyle başka kıtalara yayılması (Şenel, 2008, s. 88), kendi varlığını yeni mekânlarda nesneleştirmesi, dışsallaştırmaş sonucunu doğurmuştur. Zamanla bu göç hareketleri durmadan devam etmiş ve her çağda neden ve sonuçları değişse de varlığını sürdürmüştür. Modernleşme ise göç süreçlerini giderek daha karmaşık bir olgu haline dönüştürmektedir. Sanayileşme ve kapitalizmin gelişmesinin en 
önemli sonuçlarından birisi göç süreçlerine ivme kazandırarak hem ülke içinde hem de ülke dışına göçü arttırması olmuştur. Boşalan topraklar kentlerin doluşuyla telafi edilmiş (Hobsbawm, 1996, s. 341), tarımda makineleşme ile kırsal kesimde işsiz kalan milyonlarca insan kentlere göç etmiş ve orada yeni bir yaşam kurmaya çalışmıştır. İkinci Dünya Savaşı'nın bitişiyle birlikte göçün önemi ve hacmi artmakta, küreselleşme hareketi içerisinde "kilit bir dinamik olarak" yerini almaktadır ve modern çağ "göçler çağı" olarak nitelenmektedir (Castles ve Miller, 2008, s. 3, 7). Artan göç, klasik olarak göç alan yerlerde ulusal kimliğin sorgulanmasına yol açmıştır. Başlangıçta "Milliyetçi retorik, bir ülkenin kimliğini kavramlaştırırken, az çok karşılaştırılabilir başka birimlerin varlığını” öngörmektedir (Calhoun, 2012, s. 129). Dolayısıyla herhangi bir bireyin ya da grubun kimliğini oluşturacak karşılaştırma ve referans noktası "öteki”nin varlığını gerektirmektedir. Bu yüzden göç her zaman kendine özgü yeni bir insan tipi ve öteki yaratmakta, onu dönüştürmektedir.

Göç olgusu daha ulusal ve yerel ölçeklerde değerlendirilip "iç", daha ulus aşırı ve evrensel ölçeklerde değerlendirilip "dış" göç olarak nitelendirilse de, insanlığın ulaştığı aşama, yeni kavramların belirmesine neden olmaktadır. Örneğin "beyin göçü" ya da modern, siber toplumsal yaşamda ortaya çıktığı biçimiyle "sanal mekânlara göç" ve kendini orada var etme çabaları, göçü zaman ve mekânın ötesinde "boyut" olarak da değerlendirmeyi gerekli kılmaktadır. İnsanlık tarihinde yeni olarak nitelendirilecek bir olasılık ise şimdilik kısmen "bilimkurgu" olarak görünen yıldızlararası yolculuklar vasıtasıyla başka dünyalara göçtür. Ekim 1957'de Sovyetler Birliği'nin Sputnik adlı ilk uydusunun uzaya fırlatılması ardından insanlık artık bu gezegenden çıkabilme yeteneğine kavuşmuştur. Aynı zamanda uydunun dünya üzerinde çektiği fotoğraflar da sınırsız değil, oldukça sınırı bir dünya kaynakları görüntüsü sunmuş ve insanlık yaşam mucizesinin kırılganlığına şahit olmuştur. Bu durum yeryüzüne dönük bakış açısını dönüştürmüş, sınırsız uzaydaki başka mekânlara yerleşme arzusu artmıştır (Aldiss ve Wingrove, 1988, s. 427). Her ne kadar Dünya gezegeni insanlığın şu an yaşayabildiği tek gezegen olarak görünse de, bu gezegenin tek yerleşim alanı olarak kalacağına dair bir karamsarlık henüz kimsede hâkim değildir.

Bilimkurgu türü büyük ölçüde bir "mülteci" türüne (Anders, 2008), yani belli bir yerde yaşayamayan, yeni vardığı yerde yabancılık çeken insanlar hakkında bir türdür³. Bilim-

3 En bilinir uzaylı mülteci figürlerinden birisi Superman karakteridir. Kripton gezegeni yok edildiğinde son anda dünyaya gönderilen Superman, uzun yıllar boyunca kendisini "dünyalı" sansa da işin aslını büyüdüğünde öğrenmiştir (Anders, 2008). Bilimkurgu eserlerindeki göç ve göçmenlere ilişkin pek çok eser bulunmaktadır. Edebi eser olarak örneğin Brain Aldiss'in bu temadaki ilk eserlerden olan romanı Starship (1958) (Yıldız Gemisi, 1999) içinde nesillerin yaşadığı bir yıldız gemisi ve onun sakinleri hakkındadır. Aldiss bu eserinde Procyon adlı bir gezegenin kolonileştirilmesinden dönen bir nesil yıldız gemisinde geçen olayları betimler. Robert Heinlein'ın Orphans of the Sky (1964) eseri de benzer bir konuyu ele alır ve Vanguard adlı gemide ortaya çıkan bir isyan ile ölen mürettebat, bu mürettebattan kalanların teknolojik geri çekilme ve tıpkı Aldiss'in romanında olduğu gibi kendilerine yeni bir mit yaratışlarını betimler. Yanı sıra Ursula Le Guin'in Mülksüzler (The Dispossessed, 1974) romanının merkezinde Anarres ve Urras adlı çatışma içindeki iki farklı dünya arasında bir etkileşim kurmaya çalışan bir mülteci bulunur. Arthur Clarke'ın Rama Bahçesi (The Garden of Rama, 1991) adlı kitabı, uzay gemisine (zorla) yerleştirilmiş mülteciler ve suçluların ideal bir düzen ve yaşamı kuramayışlarını gösterir. Bu türden örnekleri TV dizilerinde de bulmak mümkündür. Battlestar Galactica dizisi (2004-2009) dünyaları Cylons adlı makineler tarafından iki kez ele geçirilmiş insanların mülteci haline gelişleri ve kendilerine yeni bir yuva bulma çabaları hakkındadır. Babylon 5 (1994-1999) dizisine ismine veren uzay istasyonu mültecilere ev sahipliği yapan, barışın tesisi için yapılmış bir yerdir. Televizyon tarihinin en uzun soluklu serisi olan Star Trek'in çeşitli bölümlerinde bu türden nesil yıldız gemileri konularının işlendiği bölümler bulmak mümkündür. Örneğin Orijinal 
kurgu ile ilişkilendirilen ilk imgelerden biri uzay gemileri ve uzay yolculuğudur (Seed, 2011, s. 6). Uzayın sınırsızlığın sunduğu cazibe ve olasılıklar ilk bilimkurgu yazarlarının o dönem tamamlanmakta olan Dünya'daki keşif hareketlerini uzaya taşımaları sonucunu doğurmuştur. Bununla birlikte uzayın sınırsızığının yarattığı olumsuz bir durum da söz konusudur. Evrenin büyüklüğü, en yakın yıldız sistemlerinin bile en gelişmiş teknolojik araçlarla ulaşılmasının büyük zamanlar gerektirmesi "uzayın kolonileştirilmesi" sürecini zorlu bir süreç olarak ortaya koymuştur. Bu sorunu çözmek için nesil yıldız gemileri (generation starship) fikri öne sürülmüştür.

Nesil yıldız gemileri kavramının oluşması için öncelikle insanın doğa ve evrene bakış tarzında bir değişiklik gerekmektedir. Bunun için Dünya'yı ya da Güneş sistemini evrenin merkezi olarak gören dünyamerkezli bir görüşten uzaklaşıp, bilimsel bir bakışın hâkim olduğu bir paradigmaya geçiş gereklidir. Charles Sheffield'ın görüşlerine kısmen benzemekle birlikte (Akt. Caroti, 2009, s. 2), belli bir tarihsel dönemlendirme değil ama süreç olarak bazı gelişmelere dikkat çekmek mümkündür. Giardano Bruno'nun evren ve güneş sistemi hakkındaki görüşlerinden dolayı yakılması, Kopernik Devrimi, Isaac Newton'un kütle çekim yasaları bu tür bir düşüncenin oluşması için merkezi etki yaratmıştır. Bunun yanı sıra gök cisimlerinin sınıflandırılması, aralarındaki mesafelerin ölçülmesi bir başka gerekliliktir. Son olarak ise makro düzeyde uzay yolculuklarını yapılması için Görelilik Kuramı gibi bütünleştirici kuramların ortaya çıkması ve yolculuk için gerekli teknolojilerin (en azından fikir düzeyinde) ortaya konması gerekmektedir. Nesil yıldız gemilerinin fikir olarak ortaya çıkması da, yirminci yüzyılın başında Albert Einstein'ın özel ve genel görelilik kuramının kabul görmesi ve ispatlanması gibi gelişmelerin sonrasına rast gelmektedir.

Caroti'ye göre nesil yıldız gemileri kavramı, ışık hızından daha hızı hareket eden ulaşım araçlarının mümkün olmadığı bir teknolojik seviyede, insanlığın bu mesafe engellerini aşması için çözüm olarak üretilmiştir. İnsan yaşamının farklı uzamlarda sürdürülmesi konusunda uzayı ve uzay yolculuğunu ortaya koyan öncü çalışmalar John Desmond Bernal, Konstantin Tsiolkovsky ve Robert Goddard tarafından yapılmıştır. Bu isimler bu açıdan nesil yıldız gemisi düşüncesinin "babaları" sayılabilir. Goddard 1918 tarihli The Last Migration (Son Göç) adlı çalışmasında, insanlığın nesil yıldız gemileriyle yapacağı uzay yolculuğunun ilk olanaklarını ortaya koymaya çabalamıştır. Goddard'ın düşüncesinde bu türden nesil gemileri ve yolculuklar insanlığın son umududur. Tsiolkovsky'nin roket tasarımları ve nesil yıldız gemileriyle yolculuk, sadece araç düzeyinde insanlığı uzayın daha uzak köşelerin götürüyor görünse de, aynı zamanda kozmik süper bilinç ile temas etmenin aracılarıdır (Caroti, 2009, s. 27-28, 31, 32, 37). Bu fikrin daha geniş bir kamuoyuna ulaşmasında Bernal'in büyük etkisi olmuştur. Tsiolkovsky, Goddard ve Bernal'in düşüncelerinin özgün yönü uzay yolculuğunu ve

serinin For the World Is Hollow and I Have Touched the Sky (1968) adlı bölümü ataları tarafından Yonada adlı bir gemiye yerleştirilmiş ve çıktıları yolculukta esas amaçlarını unutmuş mültecileri merkezine alır. Benzer biçimde hemen hemen belirli bir felaket motifine sahip bütün apokaliptik ya da post-apokaliptik bilimkurgu filmleri bu türden mültecilerin hikâyelerini konu alır. Örneğin Snowpiercer (Bong Joon-ho, 2013) dünyanın bir buz küresine dönüşüp yaşamı desteklemez hale gelişiyle bir trende hayatta kalmaya çalışan mültecilerin sınıfsal mücadelelerini konu edinir. Morten Tyldum'un yönettiği Uzay Yolcuları (The Passengers, 2016) filmi benzer biçimde 120 yıllık bir yolculuk için Avalon adlı yıldız gemisinde uyutulan bir yolculardan erken uyandırılanların hikâyesini ele alır. Bu türden örnekler insanlık tarihi ile bilimkurgusal imgeler arasında bir analoji kurma imkânı yaratır ve örnekleri çoğaltmak mümkündür. 
kolonileşmeyi artık bir "kader" olarak ortaya koymuş olmalarıdır.

Bu çerçevede nesil yıldız gemileri üzerine bir tanımlamaya ulaşmak mümkündür. "Bir nesil gemisi, ya da nesil yıldız gemisi ışık hızından daha yavaş hareket eden, uzaydaki büyük uzaklıklarda yolculuk imkânı veren, varsayımsal yıldızlararası bir gemi türüdür». Bu türden bir yıldız gemisinde yolculuk edenler, en yakındaki yıldız sistemine ulaşmak için yüzyıllar boyu sürecek bir yolculuğa çıkmışlardır ve geminin ilk sakinleri büyür, yaşlanır ve ölürken, onların torunları yolculuğa devam edeceklerdir. Bu gemiler nerdeyse kendi kendine yeterli bir enerji, yiyecek, hava ve su stoklarına sahip olmalıdır. Uzun bir yolculuk yapılacağı için de bu yapının dayanıklı olması gerekmektedir (Nygren, 2015, ss. 12-13). Nesil gemilerinin en az yirmi beş yıllık bir "nesil" dönemi boyunca yolculuk yapacak gemiler olması gerektiğini vurgulamaktadır ve yıldızlararası yolculuğa imkân verecek olan gemileri şu şekilde sınıflamışlardır: Yazarlar nesil yıldız gemileri (generation ship) ve uyku gemilerini (sleeper ship) yıldızlararası gemisi (interstellar ark) ana başıı̆ı altındaki iki alt başlık olarak değerlendirmiştir. Nesil yıldız gemileri de dünya gemisi (world ship), koloni gemisi (colony ship), yavaş gemi (slow-boat) ve her iki kategoriye dahil olan hızlı gemi (sprinter) olarak sınıflanmıştır (Hein, Pak, Pütz, Bühler ve Reiss, 2012, s. 120). Görüldüğü gibi farklı amaç ve intiyaçlara uygun farklı türde gemiler yapmak mümkündür ancak bu gemilerin yapım öncesi, yapım, yolculuk ve varış aşamasında çeşitli riskler bulunmaktadır. Nygren'in (2015, s. 13) düşüncelerini de gözeterek bunları şu biçimde sıralamak mümkündür:

- Uzayda, makul düzeyde ulaşılabilir bir yıldız sisteminde, gezegen yüzeyinde biyolojik olarak yaşamın gelişmesi için yeterli fiziksel parametreleri sağlayan uyumlu bir yerin bulunması.

- Yolculuk ve geminin yapımı için destekçilerin ve sponsorların bulunması.

- Başarıya ulaşmak için gerekli mürettebat bulunması ve onların eğitilmesi.

- Destekçilerin bu yolculuk için temellendirdiği insan varoluşuyla ilgili temel değerlerin ve yönelimlerin paylaşılması.

- Geminin bakımı ve işletilmesinin sağlanması.

- Geminin mürettebatının ve yolcularının hayatta ve destekçilerin belirlediği tek motivasyona bağlı kalmasının sağlanması (Gemi dünyadan ayrılmadan bunu anlamak mümkün değildir).

- Minimum sayıda popülasyonun izolasyon halindeyken destekçilerin kabul edebileceği düzeyde varlı̆̆ını sürdürmesi.

- Mürettebat ve yolcuların destekçilerin istemediği bir yönde evrimleşmesinin engellenmesi.

- Gezegenin kolonizasyonu, araştırma, yeni yıldızlararası geminin inşası.

Nesil yıldız gemileri için hem destekçi bulmak, hem de yolcuların ve mürettebatın başlangıçtaki amaca uygun biçimde yaşamlarını sürdürmesini sağlamak çok zordur. Ayrıca bu yolculuk için optimal yolcu ve mürettebat sayısı da önem arz etmektedir. Genel olarak uygarlıktan yalıtılmış küçük grupların (örneğin 4 bin kişilik bir grup), uzun vadede teknolojik olarak geri çekilme yaşadığı, ya da daha küçük grupların (200-400 gibi) tümüyle yok olduğu görülmüştür (Hein vd., 2012, s. 122). Buradan çıkan sonuca göre uzaya küçük gruplar göndermenin kısa ve uzun vadede sıkıntılar yaratabileceğini söylemek mümkündür. 


\section{Beden Sosyolojisi, Benlik ve Kimlik}

İnsan bedeni ilk bakışta belirli bir fiziksel oluşa, biçime ve işlevselliğe gönderimde bulunsa da, renk, biçim, sağlık, güç, güzellik gibi yönleriyle hem bireylerin ve toplumun da hem de çeşitli iktidar yapılarının ilgisinin merkezinde olmuştur. Güzellik ve çirkinlik, renk ve biçimiyle ırksal aidiyet, engellilik ya da sağıklı olma kıstasları, ya da genel olarak bedenin algılanışı, onun "mahremiyeti", tarih boyunca değişen bir ilişkiler kümesine gönderimde bulunmaktadır. Dahası beden belirli edimlerin nesnesi olarak, acı verici uygulamaları deneyimleyen, dolayısıyla hep ehlileştirilmek istenen bir şey olarak görülmüştür (Scott, 1995). 1980'li yıllardan itibaren sosyolojide bir beden sosyolojisi alanı gelişmeye başlamıştır. Bu kapsamda yapılan çalışmalar bir şekilde bedene referans vermektedir. Haz, acı, iktidarın uygulanması ya da bedenin güzelleştirilmesi, bedenin sunumunun araştırılması bu alanın gelişmesine imkân tanımıştır (Işık, 1998, ss. 13-15, 120-122). Uygarlığın gelişim süreci büyük ölçüde beden üzerinde, bedensel arzular üzerinde bir denetim üzerine kuruludur. Dolayısıyla beden üzerinde iktidar kurma imkânı sağlayan kurumların gelişimi de önemlidir. Foucault'nun hapishaneler (1992) ve cinselliğin tarihi (2007), dolayısıyla beden üzerine yaptığı araştırmalar, bedenin kaçınılmaz biçimde iktidarın hedefinde oluşu, biyopolitika/biyoiktidar (2015) kavra$\mathrm{mı}$, beden sosyolojisi için geniş bir tartışma alanı sağlamaktadır. İtaat sağlama, terbiye etme, gözetleme, hazza dönük perhiz, cinselliğin edimselliği ve sapkın olanın teşhisi gibi konular bedeni belirli bir mücadelenin merkezine koymuştur. Elias'ın gösterdiği gibi (2004) uygarlığın bizatihi gelişimi, bedenin algılanışını, onun diğer bedenlerle etkileşimi üzerine kuruludur. Beden algısı tarih boyunca değiştiği gibi, bedensel edimler, bunun yarattığı utanma ya da Elias'ın kavramsallaştırdığı biçimiyle "sıkılma eşiği" (2004, s. 155), belirli eylemler ve "adabı muaşeret" kuralları "uygar" olmanın da çerçevesini çizmektedir.

Beden kavramı duyumsayan bir özneyi, bütün özelikleri ve edimleriyle bir benlik ve kimlik, dolayısıyla öteki kavramına gönderimde bulunmaktadır. Kimliği ya da ilişkilerle şekillendirilmiş biçimiyle benliği tanımlamak, ya da kendini tanıma yoluyla sunmak ilk başta kolay görünmektedir. Jung "yaygın olarak "kendini tanımak" denen şey, büyük bölümü sosyal faktörlere ve insan ruhunda olup bitenlere bağlı olan çok sınırlı bir bilgidir" demektedir (1999, s. 48). Benlik diğer insanlarla ilişki kurmayı sağlamaktadır. Dolayısıyla belirli bir toplumsallıkla ortaya çıkan bir fenomendir. Bu ilişkiler kişiye kendi benliğinin kim ve ne olduğunu, kendisine dair düşüncelerini, bireysel özelliklerini ve inançlarına dair bilgi kümesi sağlamaktadır ve bunların büyük ölçüde istikrarlı olması gerekmektedir (Kağıtçıbaşı, 2014, ss. 247-248, 250). Benlik "içerik" ve "süreç" bakımından değerlendirilebilir. İçerik olarak benlik "kişinin kendine baktığında kendinde bulduğu ya da algıladığı özellikleri (kişilik çizgileri, vücudu, yetenekleri, vb.) kapsar"ken, süreç olarak benlik bu özellikleri gören, algılayan, bilen, değerlendiren bir Ben'e, eyleyen bir özneye karşılık gelmektedir (Bilgin, 2007, s. 12). Genel olarak bakıldığında "Benlik, bireyin özellikleri, yetenekleri, değer yargıları, emel ve ideallerine ilişkin kanıların dinamik bir örüntüsü"dür (Baymur, 1994: 264-265). Lacan açısından kimlik ve benlik belirli bir referans noktası üzerinde oluşmuş bir çöküntü, bir bağlanma noktasına (point de capiton) ihtiyaç duymaktadır (Zizek, 2011, s. 15). Kendini bir mekân, zaman ve ilişki sistemleriyle ilişkilendirerek kazanılmış bir kimlik ise büyük ölçüde referans 
noktasının sabitliği(sizliği) ölçüsünde süreğen(siz) ve korunaklı(sız) bir alanda olacaktır. Buna karşın fiziksel ve sembolik olarak uzayın ifade ettiği bu sabit olamama, belirli bir yere yerleşememe sorunu kimliği tutarsız hale getirmektedir. Kişinin buradaki sahip olduğu güvence çeşitli sembollerdir. Lacan'ın dilin öncesinde bir "beden” bulunmayışı vurgusu da (Sarup, 2004, s. 18) bu nedenledir. İnsan büyük ölçüde kendisini ve diğerlerini belirli gruplara aidiyeti temelinde algılamaktadır. Bu toplumsal kimlik dolayısıyla ben ya da biz ile ötekilerin tespiti kişiye kullanışlı bir zihinsel, toplumsal harita sağlamaktadır. Kimliksizleşme ise, kişilerin bazı durumlarda grup içinde bireyselliğini yitirmesi, normal şartlarda yapmayacağı işleri yapar duruma gelmesiyle bağıntılıdır. Kişi bu aşamada anonimleşmekte, tanınamaz hale gelmekte (Kağıtçıbaşı, 2014, ss. 262-263, 268), böylece normalde bastırdığı güdü ve duygularına açığa çıkma fırsatı sağlamaktadır. Bu bakımdan kimliksizleşme, belirli uygarlık değerlerinin askıya alınması, ilkelliğe dönüş olarak yorumlanabilmektedir. Kimlik "bir kişi ya da grubun kendisini tanımlaması ve kendini diğer kişi veya gruplar arasında konumlaması" biçiminde tanımlanmaktadır. Bireysel düzeyde benlik kavramına götüren kimlik bir tür şema, ağ ve prototip olarak anlam kazanmaktadır. Bu yolla kimlik kişi için kendisi ve başkaları hakkında tanımlayıcı bilgi kümesine gönderimde bulunmaktadır. Bunun yanında yine Bilgin'in belirttiği gibi bu nitelikler hep bir öteki, ben olmayan ile ilişkilidir. Ben, benlik gibi kavramlar zorunlu olarak bir başkasını, farklı olanı gerektirmektedir. Böylece öteki onun toplumsal bir temsil olarak inşa edilmesini, bununla ilişkili olarak da dışlanmasını gerekli kılmaktadır (Bilgin, 2007, s. 11, 176). Bu tanımlardan yola çıkıldığında bedenin, bedenin "sahibi" görünen öznenin duyumsalığının, onun kendisine dönük algısının ve nitelik bilgisini genel bir süreklilik içinde ifade edilmesinin, dolayısıyla istikrarlı oluşunun Ben için temel bir öneme sahip olduğunu söylemek mümkündür. Bu yüzden benliğin dönüşümü ya da kaybı aslında bene ait görülen niteliklerin de dönüşümü ya da kaybıyla ilgili olmaktadır.

\section{Pandorum Filminin Analizi}

\subsection{Filmin Özeti}

2174 yılında insan nüfusu dünyanın taşıyamayacağı kadar artmıştır. Bu yüzden başka gezegenlerde yerleşme için çabalar başlamış, Tanis adlı gezegen keşfedilmiştir. Bu gezegene ulaşma amacıyla 123 yıllık yıldızlararası yolculuğa uygun bir gemi inşa edilmiştir. Gemide 60.000 kişi bulunmaktadır. Yolcular hiperuykuda tutulurken, mürettebat her iki yılda bir nöbetleşe uyanıp gemiyi idare etmektedir. Ancak sekizinci yılda bir mesaj alınır. Buna göre dünyadaki yaşam sona ermiştir ve gemi insanlığın son umududur. Belirsiz bir süre sonra gemideki iki kişi, Onbaşı Bower (Ben Foster) ve Teğmen Payton (Dennis Quaid) uyandırılır. Onlar kısmen unutkanlık hastalığı geçirmektedirler. Gemi ise elektrik sorunları yaşar. Bu yüzden kapılar açılmadığı için ana yönetim bölgesine, köprüye ulaşamazlar. Bower havalandırma sistemini kullanarak güç bölgesine geçiş yapmaya çalışır. Bower "Eksensel Disfonksyion Bozukluğu” yaşamaya başlar, bu hastalık pandorumdur. Bower, genetikçi Nadia ve tarımcı Manh (Cung Le) ile karşılaşır. Onlar bir grup ilkel, yamyam yaratığın saldırısına uğrar ve kaçmaya çalışırlar. Üçlü gemide yıllar önce uyanmış, yamyamlaşmış, Leland (Eddie Rouse) ile karşılaşırlar. Bu arada Payton onbaşı Gallo (Cam Gigandet) adında bir başkasını bulur. Gallo ekibini öldürdüğünü, çünkü onların hasta olduğunu, pandorum belirtileri gösterdiğini söyler. 
Leland, Bower'ın grubuna yiyecek verir ve gerçek orijinlerini tasvir eden duvar resimleri çizer. Çizime göre, Dünya bilinmeyen bir felaketin ardında kaybolduktan sonra Gallo belirmiştir. Ekibini öldürdükten sonra yolcuları uyandırarak ve onları kötüye kullanarak "Tanrı'yı oynamaya” başlamıştır. Zihinsel durumlarından yararlanan Gallo, çoğunlukla pandorumdan etkilenen bu yolcuları geminin büyük yük bölgesine sürükleyip dövüşmeye, yamyamlığa ve birbirlerine işkence yapmaya zorlar. Sonunda, Gallo hiperuykuya geri dönmüştür. Bıraktığı nesiller ise giderek bu yamyam kültüre adapte olmuştur ve böyle yaşamaya devam etmişlerdir. Bower ve arkadaşları büyük ölçüde yamyamlaşmış olan kişilerle mücadele ederek, mutantların arasında gemi jeneratörüne ulaşır ve sistemi yeniden çalıştırır. Hastalık Gallo'nun kişilik bölünmesi yaşamasına neden olmuştur. Yaşan son mücadelede Gallo ve Bower karşı karşıya gelir ve geminin çoktan hedeflenen gezegene ulaştığı, okyanusun içinde kaldığı anlaşılır. Bower kalan herkesi tahliye ederek yeni bir yaşam için başlangıç fırsatı sunar.

\subsection{Kaos İçinde 'Dünya'}

Bilimkurgu türünün temel özelliklerinden birisi öteki ile heyecan verici karşılaşmalar, başka dünya ve zamanlara yolculuk arzusudur; dolayısıyla bilimkurgunun kolonyal ya da emperyal ideallerin en üst aşamaya çıktığı bir dönemde ortaya çıkması arasında bir paralellik söz konusudur ${ }^{4}$. Bu keşif arzusunu Pandorum filminde de görmek mümkündür.

Keşif arzusuna her zaman bir sahiplenme ve işgal arzusu eşlik etmektedir. Bilimkurgu türü tehlikelere karşın temas ve ilk hareketin gerçekleşmesini "olmuş bitmiş̧" bir şey olarak koymakta ve onun sonuçları üzerine düşünme imkânı vermektedir. Bu arzuya kimler sahip olur sorusunun cevabını Bernal (1929) şöyle vermektedir:

İlk uzay gezginleri ve daha sonra gözlemleri dünyanın dışında en iyi şekilde gerçekleştirilecek olan bilim adamları ve son olarak, herhangi bir nedenle dünya koşullarından memnun olmayanlar, bu üsler üzerinde ikamet edecek ve kalıcı uzamsal koloniler bulmuş olacaklardır (B. II, p. 5).

Bu yeni insan tipi ve uygun teknolojiler icat edildiğinde yolculuk hazırlıkları da başlayacaktır. Filmde betimlenen uygarlığın teknolojik seviyesi bu geminin yapılmasını sağlamak için uygundur. Film ise özellikle uyandırılma ve görev değişiminin tehlikelerine dikkat çekmektedir. Bernal her ne kadar öngörememişse de Pandorum filmi derin uzay boşluğunda travmalarla tetiklenip daha büyük şiddet kazanan bir hastalığın etkileri üzerine yoğunlaşmıştır. Her ne kadar öncüler yenilik arzusunun peşinden gidip büyük riskler alsa da, sonunda Bower karakterinde olduğu gibi sevdiği kadını ardından bırakmanın getirdiği travma onu pandorum hastalığına karşı hassas hale getirmiştir.

Elysium'un görevi "Gezegeni işleme ve bir toplum yaratma"dır. Elysium'u niteleyen şey, filmde belirtildiği gibi "göçmen gemisi" olmasıdır. Umut yolculuğu başlamıştır. Ely-

4 Bilimkurgu türünün ortaya çıkışı ve yükselişi ile Britanya İmparatorluğu'nun (19. yüzyıl sonu) veya sonra ABD'nin hegemonyasının yükselişi (20. yüzyılın ikinci yarısı), emperyalist kolonyalist zirve noktaları ve paylaşım savaşları arasındaki bazı zamansal paralellikler söz konusudur. Bu konuda bkz. Neale, 2005, s. 93; Reider, 2010, s. 196; Roberts, 2006, s. 50; Roloff ve SeeBlen, 1995, s. 163. 
sium yolcuları yola çıktıklarında, tam olarak hangi görev teslim zamanı olduğu bilinmez ancak, Dünya'da beklenen savaş gerçekleşir ve insanlıktan geriye sadece mürettebat ve yolcuların kaldığı ortaya çıkar. Dünya artık yerinde yoktur. Yok olmuştur. Bu durum oldukça büyük bir zihinsel bozulmaya yol açmıştır. Dördüncü uçuş ekibinin Onbaşı üyesi Gallo amirlerini öldürür ve kalanları "yük ambarına" sürgün gönderir. Artık dünyadaki uygarlık ile bir temas mümkün değildir.

Bu aşamada film insanlığın durumunu ikili bir şekilde ortaya koymaktadır: arzu ve kader. Arzular sınırsızdır ama insanlığın "kaderi" onu kaçınılmaz bir sona götürmüştür. Savaşın sonunda gezegen tümden yok edilmiştir. Dolayısıyla "kader olarak insanlığın geleceği"ne dair umutsuz bir tavır takınan film, bu kopma noktasında, yani insanın bu kaderi alt üst edip kendi kaderini eline alacağı, "yeni” bir yaşam kurarken aynı zamanda kendi özsel kimliğini de koruduğu bir zirve noktasını anlatı yoluyla sunmaktadır. İlk sınavlardan birisi iyilerin kazanıp kazanamayacağı, kazanmak için yeterli cesarete sahip olup olmadıkları, ikincisi, buna bağlı olarak uygarlık değerlerinin korunarak yeni bir yaşam ve düzen başlatılıp başlatılamayacağıdır. İnsanlığın bu “artıklarının” yüzleşmesi gereken temel sorun budur.

Filmde betimlenen dünya büyük ölçüde keşif arzusunun yönlendirici ilke olduğu değil, zorunlulukların ve kasvetin hâkim olduğu bir dünyadır. Sıkışmışlık hissi ve baskıdan kurtulma sembolik olduğu kadar fiziksel bir ayrılışı da zorunlu kılmaktadır. Zorunluluklar dünyasından özgürlükler dünyasına geçiş olarak anlam kazanacak yolculuk var oluşu anlamlı kılıyor görünmektedir. Dolayısıyla filmin serimlediği, ya da başlangıç durumu olarak ortaya koyduğu şey insanlığın hem bir arzu ve keşif hem de bir zorunluluk olarak başka dünyalara göç etmek durumunda kaldığı, bunun da büyük bir yıkım sonucunda insanlığın son şansı ya da umudu haline geldiği yönündedir. Dolayısıyla Bernal'in "kader" (B. I, p. 1) vurgusu filmde karşılık bulmaktadır ve savaş dünya yaşamını sona erdirirken, teknolojik yetkinlik başka gezegenlere göç imkânı tanımaktadır.

\subsection{Yeni Çevrede Dönüșen ‘Beden’ler}

Filmin başlangıcında, Bower uyandırıldığında ne olduğunu tam anlamamaktadır. Aslında kendisinin bile kim olduğunu bilmemektedir. Kimliği tanımlayacak özellikler listesi ya da özel işaretlerden mahrum gibidir. Dolayısıyla Bower'ı uygarlığa bağlayan tek unsur "dil"dir; kendini unutabilir ama dilini asla unutamamaktadır. İsminin Bower olduğunu, uyku bölmesindeki ismi okuyarak öğrenir. Dil onun kendini tanımasında bir anahtar işlevi görmektedir. Sonrasında bu tanıma, kendisini Bower olarak kabul etme, yol gösterici olur ve hemen Bower yazan dolaba gidip orada üniformasını giyer. Dolayısıyla dil kahramana görevini anımsatır, o bir "görev adamı"dır. Bu "adı konmuşluğun" sonucu olarak kendi benlik ve kimliğini açığa çıkarmaya çalışır. Filmdeki geçici hafıza kaybı aslında uygarlığın temel yönlendirici ilkeleriyle uzun süreli bir temassızlığın sonunda, bireylerin barbarlaştığı, ilkelleştiğini ifade etmektedir. Pandorum hastalığının belirtilerinin bastırılması, onları görünür kılmama yönündeki bir tedavinin sonuç getirmeyeceği açıktır. Asıl bu sorunun kaynağı çözüme kavuşturulmalı, uygarlıkla bağ kurulmalı, kimliği oluşturacak düzeyde "toprakla" temas sağlanmalıdır. Uzay gemisinin sonsuz uzayda "askıda" kalmış hali bütün temel değerlerden uzaklaşma güdüsü ve sonucu doğur- 
maktadır. Bunun sonucu ise bedensel hastalık belirtilerinin kimliği süreksizleştirmesi, benliğin yeni düzeyde bir yamyamlık, mutantlık ekseninde yeniden inşası olmaktadır.

Filmin bir sahnesinde Bower elinin titremesinin ardından, Payton'a pandorum etkilerini hiç gösterip göstermediğini sorar. Payton ise Eden görevini anımsatır. Eden görevindeki subaylar da pandorum, yani yörüngesel bozukluk sendromuna yakalanmıştır. Kendilerini lanetlenmiş olarak hisseden ekip gemiyi tahliye eder ve yeni dünyaya gönderilen ve uykuda tutulan herkesi uzaya fırlatır. Bu metaforik düzeyde "verimli" rahmi tohumlamak yerine, tohumların düşünmeden etrafa saçılmasıyla benzerdir. Böylece beş bin insan ölüme terk edilmiştir. Bower "en azından başıboş giden bir tabut”ta uyanmadıklarını söylerken, Payton hiç de bunun böyle olmadığını söyler ve filmin sonuna ilişkin bilgi verir. Bu yönüyle Pandorum, aslında hedefine ulaşmış, toprağa temas etmiş, ancak uygarlığın tohumlanması ve büyümesi için son adımı, yolcuların bu bereketli topraklara salınmadığı bir ara durumu konu almaktadır. Yolculuk 123 yılda tamamlanmış ancak bu inişin gerçekleştiğinin bilinmediği 923 yıl geçmiştir. Sonuçta askıya alınan uygarlığın temel ilke ve değerleriyle temastır.

Pandorum rahatsızlığının herkesi etkilemesi söz konusu değildir ancak neden bazı insanları etkiliyor bu biraz belirsiz görünmektedir. En açıklayıcı bilgi tarımcı ekip üyesi tarafından verilir: Tanis gezegenine uyumlu hale gelmek için vücuda yapılan çeşitli enjeksiyonlar bazı insanları dönüştürmüş ve yamyamlaştırmıştır. Bunun yanı sıra başka bir açıklamayı psikolojik dengesizlik, tutarsızlık, uygarlığın sınıında bulunarak, yamyamlık yoluyla uygarlığın temel değerlerine dönük ihlal edimi üzerinden yapmak mümkündür. Dolayısıyla esas sorun bireyleri topluma bağlayacak toplumsal ve zihinsel bir haritanın yokluğudur. Böyle bir haritanın yokluğundan kaynaklı kişiler kimliksizleşirler. Film yamyamlar arasındaki oluşan ritüel ve kültürün çevre etkisiyle, Gallo'nun onları zorlamasıyla oluştuğunu göstermektedir. Dolayısıyla bedenin dönüşümü önce zihnin dengesizliğiyle tetiklenmekte, sonrasında yeni çevrede zorlanan insanlar canavarlaşmaktadır. İnsanlığın tarihi onun ağırlıkla çevresel şartlara ayak uydurup varlığını devam ettirmesi üzerine kuruludur ve bedenin işleyişini anlamaya başlaması ise çok yenidir (Bernal, 1929, B.III, p.1). Dolayısıyla insan henüz kendini dönüştürme evresine yeni yeni girmektedir ve Pandorum filmi bu "uyarlanma" sorununu merkezi bir sorun olarak ortaya koymaktadır. Yeni çevresel şartlara uyarlanan insan giderek insanlığını kaybeder ve bu süreçte yamyamlaşır. Bu durum çatışkılı bir durum ortaya koymaktadır. İnsan bir yandan "kendini korumalı" öte yandan yeni koşullara "ayak uydurmalı"dır. Göçebe kültürün de temel sorunsallarından birisi neyin korunacağı, dışarıdan neyin kalacağıdır. Eğer insan kendi bedenini düzenleme imkânına sahipse neyi korumalı ve ne ölçüde kendinden vazgeçmelidir? Film bu konuda temel uygarlık değerlerini öne çıkarmaktadır. Bedenin dönüşümünü bir tehdit olarak göstermektedir. Bu dönüşümün kötücül olmasının en büyük sebebi "toprak ana" ile gerçekleştirilmiş temasın yok olmasıdır. Zaten pandorum rahatsızlığı yörüngeden uzaklaşma ile ilgilidir: Titreme, kaşıntı, uzay boşluğunda olmanın biyolojik yan etkileri bunlardır. Duygusal bir travmadan tetiklenir. Dolayısıyla pandorum vakasının uzay boşluğunda ortaya çıkmış bir hastalık olmasıyla, giderek insanlıktan ve uygarlıktan uzaklaşan mürettebatın uygarlığın "yer çekimi"nden uzaklaşması arasında bir paralellik söz konusu olmaktadır. Zihin "özgür" kaldığında beden ona eşlik etmekte bilindik formunu kaybetmektedir. Bu açıdan top- 
lumsal bir varlık olarak insan, kendini karşılaştırabileceği bir uygarlıktan yoksun kaldığında, toplumsal benliğini inşa edememekte, onu yeniden üretememektedir.

\section{4 İnsan Olmanın Anlamı: 'Șeytan' ve Uygarlık}

Gelecek tek tipte bir insan formunun değil, her biri çeşitli intiyaç veya beğenilere göre oluşturulmuş farklı tipte insanların oluşturulmasına imkân tanıyacak bir süreç olarak benimsemektedir (Bernal, B. III, p.8). Bununla birlikte bedenin metamorfozu ağırlıkla bir kimlik kaybıyla ilişkilendirilmektedir ve Pandorum filmi de bu eğilimi takip etmektedir. Örneğin Bower karşılaştığı yaratıkları "hayvan" olarak ifade eder. Onlarla nasıl iletişim kuracağını bilemez. Geçmişte pek çok eğitim almış olsa da yapılan ilk temas, bu ilişkinin nasıl sürdürüleceğine dair tüm "prosedürleri” anlamsız kılar. Onlarla "konuşulamaz" çünkü karşısında konuşmayan, sadece saldıran ve iletişim kurmak istediğinde borulara vurarak ses çıkaran bir tür, öteki vardır. Bu yönüyle insanın ilkel benliği ve arzularıyla gireceği etkileşimin hemen hiçbir bilindik formu yoktur ve yıkıcı duygulara karşı en yıkıcı davranış biçimleri tek "iletişim" biçimi olarak filmde öne çıkmaktadır. Öteki ile ilk karşılaşma, garip ve korkutucu, tekinsiz bir ortamı haber veren sesler eşliğinde gerçekleşir. Bower hemen korkuyla kaçar ve saklandığı yerden "öteki”ye baktığında, ilkel bir barbarla karşılaşıyormuş gibi davranır. Yaratığın sırtındaki sivri metalik çıkıntılar, dezenformasyona uğramış beden, solgunlaşmış ten, irileşmiş göz, keskinleşen yırtıcı dişleriyle öteki tam olarak şeytani bir ilkellik görüntüsü sunmaktadır. Onlardan en iyi gizlenme yolu kokusuz hale gelmektir; çünkü bu "yaratıklar" avlarını koku ve hareket yoluyla bulmaktadır. Bu durum avcılardan gizlenmek için kendi kokusunu gizleyen avlar için normal bir tavırdır. Kahramanın mekânsal yolculuğu zamansal bir tersinmeye yol açmış, modern insan ile ilkel vahşi karşılaşmış gibidir. Filmdeki ötekiyle, ya da şeytanlaşmış, uygarlığın dışına çıkmış ötekiyle temas temel olarak insanlığın eski bir aşamasında, henüz uygarlığın en önemli kurallarıyla karşılaşmamış, bunları özümsememiş bir "geçmiş" ile karşılaşmakla aynıdır. Bu yüzden başka dünyalara geçiş ve orada yaşam hakkı kazanma, en ilkel güdülerle savaş sonrasında gerçekleşmektedir. Bu yönüyle savaş uygarlık değerleriyle ilkellik, barbarlık arasında geçmektedir.

Filmde iyi ve kötü arasında oldukça kesin ayrımlar vardır. Yamyamlık kötüdür ve yamyamlar mutlak ötekidir; onlar bir tabuyu, insanın kendi türünden bir başkasını yememesi kuralını ihlal etmişlerdir. Freudyen tabular önceki nesiller tarafından dıştan dayatılmış ilksel yasaklardır. Bu belirli arzulara dönük yasaklar tüm insanlarda ortak olan bazı eğilimlere hitap etmektedir ve bu yasaklar sapkın düşünceleri uzaklaştırmaya dönük bir araç olarak ortaya çıkmaktadır. Tabuyu ihlal eden de tabu nesnesi haline gelmektedir ve uzak durulması gerekmektedir. Yasak olanı gerçekleştiren kişinin tabu haline gelmesinin sebebi bu yasağı delip, diğerlerinin aklına bu yasağın kırılabileceği düşüncesini sokan ve onları "ayartan" kişi olmasıdır (Freud, 2012, s. 83). Bu durum da Freud'un yine vurguladığı gibi arzu ve yasağın çifte değerli olduğunu göstermektedir. Bununla birlikte yamyamların varlığı, var oluş nedeni (rasion d'etre) filmdeki olayları "anlatılmaya değer" kılmaktadır. Bir kez kendi türünden birisini sebepsizce öldürüp tabuyu ihlal eden kişi, bundan dolayı cezalandırılıp tabu haline gelmediğinde tabuyu ihlal etme güdüsü diğerlerine de bulaşmakta, ilk yamyamlık edimiyle birlikte bir yamyamlık 
kültürü oluşmaktadır. Böylece canavarlar uygarlığa giden yolda topluca katledilmesi gerekenlerdir. İyi ve kötü olarak bölünme gerçekleşmiştir. Sonuçta öteki, Ben'in/Biz'in sağaltımı için olumsuz bir toplumsal inşa olarak görevini yerine getirmiştir

Temel dikotomiler yoluyla çatışma sadece değerler değil, filmin öncesinde Payton olarak görünen Gallo kahramanının kişisel özellikleriyle de belirginleşmektedir. Gallo'nun kolunda $F L T>>004>016$ kodu işaretledir ve bu onun dördüncü uçuş ekibinde olduğunu göstermektedir. Gallo kendisinin değil, diğer iki uçuş ekibinin pandorum olduğunu söyler. Onları öldürmüştür. Sonunda Gallo olarak beliren kişi ile Payton olarak belirtilen kişinin savaşımının aslında kişilik bölünmesi olduğu ortaya çıkar. Onlar tek kişidir. GalIo’nun filmde söylediğine göre Tanrı insanlığın geri kalanıyla birlikte ölmüştür. Kanun ve düzen yoktur. İyi veya kötü; artık bunların bir anlamı yoktur. Ahlak zincirinin bir parça bile kırılması gerçek bir "özgürlük”tür, daha doğrusu bastırımış arzuların özgürlüğüdür. Başlangıçtaki o korkulardan arındığında saflık, aydınlanma yaşanır. "Eski dünyadan" arta kalan değerler kişinin sırtında taşıdığı ağır bir yüktür. Buna karşın film uygar insanın bakışını öne çıkarmaktadır. Dışarıdakiler, ötekiler, yamyamlar, kural tanımayan, ahlaki ilkelere uymayan, barbar, ilkel varlıklardır. Grup haline yaşarlar; bireysellikleri yoktur. Bunun en tipik görünümlerinden biri hepsinin reaktörün eteklerinde bir grup halinde, birbirlerine sokulmuş biçimde uyumalarıdır. Birbirlerinin sıcaklığına ihtiyaç duyarlar ama en ufak bir yara aldıklarında ya da öldüklerinde de kendi türünden birini yemekten geri kalmazlar. Bunun sebebini Schopenhauer söyle ifade etmektedir: “... herhangi bir insan kalabalığı, her türlü yasadan, düzenden kurtulduğunda...bellum omnium in omnia [herkesin herkesle savaşı] bir anda en seçik biçimiyle gözlerimizin önüne serilir" (2009, s. 248). Böylece Hobbesçu değerlerden "arınma”, düzenleyici normun yoksunluğu gerçek bir vahşet dünyasının oluşmasına neden olmaktadır. Bu yüzden film uygarlığın üzerine kurulu olduğu tabuların yeniden inşasını yeni bir anlatısal denge durumu için gerekli görmektedir.

Filmin genel konumu sekülerlikten yanadır. Görünüşe bakılırsa pandorum vakası yaşayanlar ortama uyum sağlarken dinsel bir ritüel kültürü de oluşturmuşlardır. Dolayısıyla filmde din, ya da etik kurucu ilkesi daha iyi bir yaşam olmayan din "geri gidiş"in önemli araçlarından birisi olarak ortaya çıkmaktadır. Bununla birlikte dinsel imgeler, ya da mitos haline gelen gerçeklik dinsel hikâyeler yoluyla piktografik bir bellek imkânı sunmaktadır. Bower bu piktografik imgeler yoluyla geçmişte ne olduğunu öğrenmiştir; bu da filmde mitin olumlu bir işlevi olarak görünmektedir.

Bernal "Yeni insan, daha önce onu düşünmemiş olanlara garip, canavarsı ve insanlık dışı bir yaratık olarak görünmelidir fakat o, şu anda var olan insanlık tipinin yalnızca mantıksal sonucudur" (1929, B.III, p.11) demektedir. Bernal'in bu öngörüsü büyük ölçüde Pandorum filmi için de doğrudur ve öteki, canavarsı, kötücül ve uygarlık dışı bir konumda yer almaktadır. Bununla birlikte bu sıfatların, yani garip, canavarsı ya da insanlık dışı olanın belirli türden bir gelecek değil, büyük ölçüde geçmişteki insanlık durumunun korkularıyla yapılandırılmış olması filmde öne çıkan bir olgudur. Filmde ötekinin şahsında dönüşen beden "insanı kemiren" bir bedendir. Onun varlığıyla insanın varlığının aynı yerde bulunmasının olanağı yoktur. Kötü olan geçmişteki anılardır. Herkesin herkese karşı savaştığı ilkel durumdur. Bu yönüyle filmdeki kötücül imgenin, ya da "Şeytan"ın sonunda insanın bastırılmış, uygar olmayan arzuları olduğunu söylemek mümkündür. 


\subsection{Bir Sentez Çabası: Arzu ve Kader}

Filmdeki Elysium gemisi aslında bir "nesil yıldız gemisi" olarak tasarlanmamıştır; sınıflamada belirtildiği gibi bir "uyku gemisi" olarak mürettebat ve yolcuları sağlıklı biçimde hedef gezegene ulaştırmak için yapılmıştır. Gemiyi ve yolculuğu planlayanlar muhtemel kültürel kayıpları en aza indirmek için bu türden bir formül bulmuşlardır. İnsanlığın derin uykusunun yeni bir uygarlık şafağının doğmasına yol açması beklenirken, uykudan uyanan insanın en ilkel içgüdüleri olmuştur. Esas tehlike geminin giderek doğal yollarla bir nesil yıldız gemisine dönüşmesiyle başlamıştır. Bu tür bir amaç için tasarlanmayan uyku gemisi, özellikle bir bireyin (Gallo) uygarlık değerlerinin dışına çıkmasıyla tetikleyici dönüşümü geçirir ve gemideki insanların giderek yamyamlık gibi eğilimlere dönüş yaptığı bir nesil yıldız gemisi olur. Her bir nesil sonrasında doğanlar ve büyüyenler insanlığın en temel değerlerini daha fazla unutur ve yamyamlık bir norm halini alır. Filmde yamyam yaratıklar artık üremekte ve soylarını devam ettirmektedir. Masumiyetin simgesi sayılan çocuklara karşı nasıl davranılmalıdır sorusu bir sahnede açıklığa kavuşur. Bower ve takımı yamyam kültür içinde yetişmiş bu çocuğa karşı ne yapacaklarını bilemez. Öldürme teşebbüsü ekip üyesi tarafından hemen engellenir. Buna karşın çocuk kaçar, türdeşlerini çağırır. Filmin sonuna doğru büyük çatışma anında ise çocuk ona "acıyan" insanın boğazını hiç düşünmeden keserek öldürür. Böylece film büyümüş ve yıkıcı etkilerini görünür hale getirmiş olanlar için değil, "saf" görünen çocuksu arzuların bile tavizsiz biçimde yok edilmesi gerektiği söylemini öne çıkarmaktadır. Filme göre uygarlık/barbarlık dikotomisinde çocuksu ve saf gibi niteliklerin anlamı yoktur ve kötücül şeylerin hepsinden uzaklaşılması, yok edilmesi gerekmektedir.

Bower kendisine saldıran ve yardımcı olanların aralarındaki savaşı silahını havaya ateş ederek durdurur. Böylece parçalanmış, "herkesin kendi başının çaresine baktığı" bir ilişki biçimi yerine, daha uyumlu ve ortak amaç çerçevesinde bir araya gelmiş bir birliktelik vurgusu yapılır. Kişileri bir araya getiren şey bir tür "toplum sözleşmesi"dir. Reaktör etkinleştirildiğinde sanki uygarlığın temel değerleri yeniden etkin duruma geçecek gibidir. Bower ayrılmış birimleri bir araya getirerek insanın toplumsal varoluşuna dikkat çekmekte, ortak bir yaşam ve toplumsal ilişkileri öne çıkarmaktadır. Bower'ın da yaptığı "dayanışma" vurgusunun anlamı budur. Bu sözleşme ve dayanışma etrafında filmdeki güç dengesi yamyamlara karşı insanlar lehine değişmeye başlar.

Bower'ın reaktöre ulaşıp, orada altında yatan canavarların üstünden geçişi, çoktan ölmüş, kötülüğün tarafına geçmiş, artık gazap çekmeye terk edilmiş cehennemdeki ruhların arasından geçmesine benzetilebilir. Bu yaratıkların kendilerine ev olarak hayat veren jeneratörün etrafını seçmesi metaforik olarak anlamlıdır. Hayatın kaynağının yanında dururlar ve onların yanında geçmek, en ilkel içgüdülere karşı koyarak, geçmişin travmasını atlatarak hedefe varma anlamını taşımaktadır. Böylece Bower içgüdülerine karşı direnmiş ve hayatın kaynağı reaktöre ulaşıp onu yeniden başlatarak uygarlığın devamını sağlamak için önemli bir çaba sarf etmiştir.

Film geçmişe ilişkin bir nostalji sunmamaktadır. Karakterlerin önlerinde bir gelecek vardır. Gemi tamir edilmeli, bu bakir topraklar insanlıkla, onun kültürüyle biçimlendirilmelidir. Filmin sonunda kesin gibi görünen uygarlık değerlerinin yeniden uygulanması, Tanis gezegenindeki toprağın, kapsüllerle tahliye edilen insanların su üzerinde 
uyanmalarının metaforik anlamının ifade ettiği gibi, başarılı bir şekilde "döllenmesi"dir. Kalan son insanlar güvenli biçimde gezegenin yüzeyine gönderilmiştir. Belirsiz olan ise ilkel yaratıkların hepsinin ölüp ölmediği, diriltilen insanların bu gezegende yaşayıp yaşayamayacağı ve gelecekte tıpkı terk edilmiş dünya gibi bir bölünme ve savaşın kaçınılmaz olup olmayacağıdır.

Bernal ilgili makalesinde geleceğe dair umutludur. Ona göre insan geleceği arzulayarak onu biçimlendirmekte ve biçimlendirme sürecinde farklılaşıp ve farklılaşan insan olarak dönüşüm geçirmektedir (1929, B.V, p.8). Pandorum bu türden bir farklılaşmayı olabilecek en uç sınıra kadar götüren bir film olarak ortaya çıkmaktadır ve ötekinin sonunda kötücül ve tehditkâr olduğu varsayımını kabul etmektedir. Filmde ilkelliğe dönüş metaforu yoluyla Id'in arzularının bastırılması önerilmiştir ve bu konuda en küçük bir tavizin bile yıkım ile sonuçlanacağı vurgulanmıştır. Film yıkıcı duygulara karşı yıkıcı bir saldırganlığı olumlamaktadır; süperego kurumsallaşmalıdır. Filmin söylemine göre hemen hemen tek kurtuluş budur; onlarla etkileşime girmenin en "ussal" yolu da budur.

\section{Sonuc}

Bilimkurgu türü bir keşif arzusu kadar fethetme arzusunun dışavurumu olarak anlam kazanmaktadır. Bununla birlikte öteki ile temasın her zaman korkutucu olduğu, dolayısıyla bu temasın kimlik kaybına yol açacağı korkusu filmlerde ortaya çıkmaktadır. Başka diyarlarda ya insandan daha güçlü türler varlığını sürdürüyorsa? Onlarla bir savaşım sürdürmek "mantıklı" değilse? Ya bu türler "en az" insan türü kadar başkaları üzerinde iktidar kurma ve bunu süreğenleştirme peşindeyse? Bu yeni mekân ve zaman insanın kimliğini ve varoluşunu sonsuza kadar değiştirirse? Bu türden sorular ve korkular Pandorum'da da karşılığını bulmaktadır. Bu bağlamda film insanlığın geleceğini, aşırı nüfus sorununun başka gezegenlerde hayat kurma imkânı aramaya zorladığı bir düzlemde değerlendirmektedir. Pandorum, esas olarak insanlığın uygarlık ile barbarlık sınırında kaldığı, muhtemelen kötümser bir ara formül olarak uygarlık dışına çıkmasına sebebiyet veren unutkanlık, titreme, kaşıntı ve halüsinasyon ile başlayan bir hastalıktır. Filmde kıyamet sonrası dönemde, uygarlık dışına çıkan canlıların egemen olduğu, kural ve ahlakın ortadan kalktığı bir geçiş dönemi ele alınmaktadır. Uygarlığın yeniden işler hale getirilmesiyle, herkesin herkese karşı savaştığı, yamyamvari durumun ortadan kaldırılması bir gereklilik olarak görülmektedir. Filmin sonunda yeni bir başlangıcın yapıldığı "ütopik” iyimser bir son görülmektedir.

Filmde uygarlık fenomeninin inşa edilmiş bir sembolik ilişkiler sistemi olduğu, insanların uygarlığın kurucu unsurlarıyla bağını yitirdiğinde yeniden barbarlaşacağı öngörüsü gerçekçidir. Nesil yıldız gemilerinin de en önemli sorunlarından birisi bu uygarlık temasının yitirildiği durumda kurucu normların neler olacağıdır: Bernal'in tasviri açısından bakıldığında metaforik "şeytan" orada durmaktadır. Uygarlık ancak ona sahip çıkıldığında, filmde ima edildiği üzere kendi iyi ya da kötücül "kurbanlarını" vermeye hazır olduğunda inşa edilir görünmektedir. Dolayısıyla uygarlığa giden yol barbarlığın içgüdülerinin büyük ölçüde yeni bir forma sokularak içselleştirilmesi/uysallaştırılması mekanizmalarıyla ilintilidir. Filmde bu yargıya uygun biçimde sınırı geçenler, tabuyu ihlal edenler yok edilirken, onların yeniden insan olamayacağı varsayımı öne çıkmak- 
tadır. Uygarlık da bu temel üzerine inşa edilir görünmektedir.

Göç ve göçmenlik konusu dünya üzerinde göç hareketlerinin artmasına bağlı olarak gündemde daha yoğun biçimde yer bulsa da, bu sorun ve tartışmanın uzun süreçte devam edeceğini kestirmek mümkündür. Bununla birlikte hem bilimsel çalışmaların Güneş Sistemi'nin geleceği üzerindeki projeksiyonları hem de insanoğlunun teknik olarak yetkinleşmesinin getirdiği olası riskler göç ve mültecilik sorununun sürekli gündemde tutulmasına neden olmaktadır. Bu durumun yansımasını bilimkurgu sinemasında da görmek mümkündür. Böylece başka dünyalara, sistemlere yapılacak bir göçün getireceği olası riskler, bunun genel olarak insanlık durumu hakkında yaratacağı değişimler çeşitli türde korkuların belirmesine neden olmaktadır. Şüphesiz Pandorum filminde ele alınan başka dünyalara göç konusu bu filme özgü değildir. Christopher Nolan'ın Interstellar (2014) filmi, Star Trek dizisi ve filmleri, Ridley Scott'ın Alien (Yaratık, 1979, 2017) ve kısmen Stanley Kubrick'in 2001: A Space Odyssey (1968) filmleri bu türden göç konusunu sorunsallaştıran filmler arasındadır. Filmlerde göç konusu çeşitli şekillerde ele alınmıştır. Kubrick'in eserinde göç ve öteki ile temas daha kozmik, mistik ve üstinsan diyebileceğimiz bir türsel temasa çerçeve sağlamaktadır. Nolan'ın eserinde dünyadaki durumun kötüleşmesi ve gerçekleştirilmesi gereken göç aşkın bir varoluşa geçişin zorunlu bir aşamasıdır. Bu filmler öteki ile temasın fırsatlarını öne çıkarmakta, bunu insanlık için bir potansiyel olarak görmektedir ve Tsiolkovsky'nin bu uzay yolculukların biçtiği aşkın varoluşa geçiş rolüne daha uygun yapılardadır. Star Trek dizi ve filmlerinde ise göç ve temas kimliğin kaybolmadan müzakere edildiği, her biri kendi özgün yerine sahip çeşitli varlıklarla eşitliğe dayalı bir temas biçiminde ortaya konarak insanlığın daha üst bir varlık olmasında bir aşama olarak göze çarpmaktadır (özellikle 1996 tarihli Star Trek: First Contact, Jonathan Frakes). Pandorum filmi ise, tıpkı Ridley Scott'ın Alien filminde ve sonraki devamlarında öne çıktığı gibi göç konusunu özellikle korkuların ön plana çıktığı bir düzlemde tartışmaktadır. Evrenin, yeni dünyalardaki ve uzaydaki çevresel şartların milyonlarca yıldır dünyadaki çevresel şartlara uyum sağlamış olan insan türüne nasıl bir etki yapacağı belirsizlik taşımaktadır. Film açık bir şekilde bu yolculuğun zorunlu olarak tehditler içerdiğini, bu tehditlerin bedenin transformasyonu, metamorfoz, kimliksizleşme ve hayvanlaşarak anonimleşme, benlik duygusunun yitimi gibi unsurlar içerdiğini ortaya koymaktadır. Dolayısıyla Pandorum filminde diğer filmlerde olduğu gibi göç süreci bir üst varoluşa, aşkınlaşmaya zorunlu geçiş ya da müzakere edilebilir değil, ontolojik ve içgüdüsel olarak gerileme, bu gerilemeyi durdurmaya dönük çaba olarak anlam kazanmaktadır. Diğer filmlerde öteki, yabancı fiziksel olarak başka bir varlık ve (bazılarında) öznelliğe sahip gibi görünürken, Pandorum filminde öteki ayrı değil insanın içindedir; içgüdülerinde saklıdır. Diğer filmlerde şimdiki zamanın insanı yeni varoluşu olumsal olarak iyi karşılarken, bu filmde ve Alien filmlerinde esas vurgu benlik ve kimlik duygusunu kaybetmeme yönündedir. Bu yüzden Pandorum filmini bilimkurgu literatüründe öne çıkan ve yabancı ile teması bir kimlik kaybı ile ilintilendiren, Geraghty'nin “canavarsı yabancılar” olarak belirttiği (2009, ss. 75-76) filmlerdeki temsile daha yakın görmek mümkündür. Bu tür filmlerde bilinmezlik insanlığın en derin korkularından birisi olarak belirmekte, öteki ile temas yıkıcı etkileriyle öne çıkarılmaktadır. Pandorum filminde ise bu durum daha özel olarak, öteki ile temas insanın en eski ve vahşi güdüleriyle temas etmesi olarak anlam kazanmakta, bilinmezliğin insan özünde yaratacağı değişim korkusu öne çıkarılmaktadır. 
Galaktik ya da başka dünyalara göç konusunun filmlerde ortaya çıktığı temsil biçimleri bakımından yarattığı tepkileri çeşitli kategorilere ayırmak da mümkündür. Bunlar beden, kimlik ve benliğin yenilikler ve yeni temaslar sürecinde (a) tersine evrim geçirdiği, gerilediği, kaybedildiği, (b) korkuyla korunduğu/korunmaya çalışıldığı, (c) dengeli bir biçimde neyin çıkarılıp neyin ekleneceğinin müzakere edildiği ya da (d) yenilik ve yeni ontolojik durumların sunduğu iyicil olasılıklarla açık olarak aşkınlaşma olarak karakterize edilebilmektedir. Genel olarak öteki ile karşılaşmanın getirdiği bu olasılıklar, yerelden evrensele geçişte hala en sorunlu olan şeyin genel olarak insanın kendilik (beden, kimlik, benlik, duygu ve düşünceleri, edimleri vb.) kavrayışında saklı olduğunu göstermektedir. 'Insan nedir ve ne olmalıdır?' gibi sorulara verilen dolaylı cevaplar uzaya, ötekiye ve insanın kendisine bakışını şekillendirmektedir. Göç ister istemez bilindik olandan bilinmezliğe, farklılığa geçişi ifade etmektedir ve bu temasın getireceği riskler ve fırsatlar hem insanı korkutmakta hem de sunduğu cazibe ile arzu yaratmaktadır. Kendilik duygusunu zedelemeden yeniliklere açık ve müzakereci olmak, ötekiye ve kendine bu özdüşünüşle bakmak genel olarak tavsiye edilen ideal bir durum olarak belirmektedir. Bu açıdan sonraki çalışmalarda göç sorununu ele alan filmlerde (eğer varsa) genel 'insani toplumsal öz'ün ne olduğuna ilişkin karakteristiklerin belirlenmesi, bu özelliklere ne türden ilişki, süreç, durum ve varoluşların tehdit oluşturduğunun saptanması bakımından ele alınması tavsiye edilebilir. Böylece çeşitli felsefi disiplinler yoluyla göç meselesini ele alan bilimkurgu filmlerinde insan felsefesini tartışma imkânı doğacaktır.

\section{Kaynakça}

Aldiss, B. (1999). Yıldız Gemisi. (1. Baskı). (S. Güven, Çev.). İstanbul: Metis.

Aldiss, B. W. ve Wingrove, D. (1988). Trillion Year Spree The History of Science Fiction. London, Glasgow, Toronto, Sydney, Auckland: Paladin.

Alvart, C. (Yönetmen). (2009). Pandorum [Film].

Anders, J.C. (2008). "Science Fiction is the Literature of Refugees". lo9 We come From the Future. 30 Kasım 2018 tarihinde https://io9.gizmodo.com/391068/science-fiction-is-theliterature-of-refugees adresinden edinilmiştir.

Atomic Heritage Foundations (2014). Tsar bomba. 10 Ocak 2019 tarihinde https://www. atomicheritage.org/history/tsar-bomba adresinden edinilmiştir.

Barsam, R. (2010). Looking at Movies: An Introduction to Film. (Third Edition). London and New York: Norton.

Baymur, F. (1994). Genel Psikoloji. İstanbul: İnkilap Yayınevi.

Bernal, J.D. (1929). The World, the Flesh and the Devil. 15 Aralık 2018 tarihinde https://www. marxists.org/archive/bernal/works/1920s/soul/index.htm adresinden edinilmiştir.

Bong Joon-ho, (Yönetmen). (2013). Snowpiercer [Film].

Boz, M. (2018). 2000 Sonrası Amerikan Post-Apokaliptik Bilimkurgu Sinemasında Kıyamet 
İdeolojisi. (Yayımlanmamış Doktora Tezi) İzmir: Ege Üniversitesi Sosyal Bilimler Enstitüsü.

Bilgin, N. (2007). Kimlik Inşası. Ankara: Aşina Kitaplar.

Bulletin of the Atomic Scientists (2020). It is 100 seconds to midnight. 2020 Doomsday Clock Statement Science and Security Board. (Ed. John Mecklin). https://thebulletin.org/wp-content/ uploads/2020/01/2020-Doomsday-Clock-statement.pdf

Caroti, S. (2009). The Generation Starships in Science Fiction, 1934-1977. (Yayınlanmış Doktora Tezi). Indiana: Purdue University. UMI Numarası: 3379320.

Calhoun, C. (2012). Milliyetçilik. (Üçüncü Baskı). (B. Sütçüoğlu, Çev.). İstanbul: Bilgi Üniversitesi.

Castles, S. ve Miller, J. M. (2008). Göçler Çağı, Modern Dünyada Uluslararası Göç Hareketleri. (B. U. Bal ve İ. Akbulut, Çev.). İstanbul: İstanbul Bilgi Üniversitesi.

Elias, N. (2004). Uygarlık Süreci. C. 1. (3. Baskı). (E. Ateşman, Çev.). İstanbul: İletişim.

Foucault, M. (1992). Hapishanenin Doğuşu. (M. A. Kılıçbay, Çev.). İstanbul: İmge.

Foucault, M. (2007). Cinselliğin Tarihi. (ikinci Basım). (H. U. Tanrı̈ver, Çev.). İstanbul: Ayrıntı.

Foucault, M. (2015). Biyopolitikanın Doğuşu. (1. Baskı). (A. Tayla, Çev.). İstanbul: Bilgi Üniversitesi.

Frakes, J. (Yönetmen). (1996). Star Trek: First Contact [Film].

Freud, S. (2012). Dinin Kökenleri. (ikinci Basım). (A. Tekşen, Çev.). Payel: İstanbul.

Geraghty, L. (2009). American Science Fiction Film and Television. (First Publishing). Oxford, New York: Berg.

Hein, A., Pak, M., Pütz, D., Bühler, C., ve Reiss, P. (2012). "World Ships - Architectures \& Fesability Revisited". JBIS. 65, 119-133.

Işık, E. (1998). Beden ve Toplum Kuramı. Ankara: Bağlam.

Jung, C. G. (1999). Keşfedilmemiş Benlik. (B. İlhan ve C. E. Sılay, Çev.). İstanbul: İlhan.

Kağıtçıbaşı, Ç. (2014). Dünden Bugüne Insan ve Insanlar. Sosyal Psikolojiye Giriş. (16. Basım). İstanbul: Evrim.

Kubrick, S. (Yönetmen). (1968). 2001: A Space Odyssey [Film].

Leader, A. (1969). Star Trek, TOS: For the World Is Hollow and I Have Touched the Sky [Dizi].

Neale, S. (2005). Genre and Hollywood. New York: Taylor and Francis

Nolan, C. (Yönetmen). (2014). Interstellar. [Film]

Nygren, E. (2015). Hypothetical Spacecraft and Interstellar Travel. (First Edition). Lulu.com

Project of the Nuclear Age Peace Foundation (2018). Mutual Assured Destruction. Erişim 14 Ocak 2019, http://www.nuclearfiles.org/menu/key-issues/nuclear-weapons/history/cold-war/ strategy/strategy-mutual-assured-destruction.htm. Kaynak Eser: John Lewis Gaddis, Strategies of Containment: A Critical Appraisal of Postwar American National Security (Oxford University 
Press, 1982).

Reider, J. (2010). On Defining SF, or Not: Genre Theory, SF, and History. Science Fiction Studies. 37(2). 191-209.

Roberts, A. (2006). Science Fiction. (Second Edition). London and New York: Routledge.

Roloff, B. SeeBlen, G. (1995). Ütopik Sinema. Bilimkurgu Sinemasının Tarihi ve Mitolojisi. (V. Atayman, Çev.). İstanbul: Alan.

Rymer, M. vd. (2004-2009). Battlestar Galactica [Dizi].

Sarup, M. (2004). Post-yapısalcılık ve Postmodernizm. (İkinci Basım). (A. Güçlü, Çev.). Ankara: Bilim ve Sanat.

Schopenhauer, A. (20099. İsteme ve Tasarım Olarak Dünya. (2. Basım). (L. Özşar, Çev.). İstanbul: Biblos.

Schröder, K.P., Smith, R.C. (2008). Distant future of the Sun and Earth revisited. Monthly Notices of the Royal Astronomical Society, Volume 386, Issue 1, 1. doi:10.1111/j.13652966.2008.13022.x.

Scott, G. R. (1995). İşkencenin Tarihi. (Birinci Baskı). (H. Koyukan, Çev.). Ankara: Dost.

Scott, R. (Yönetmen). (1979). Alien [Film].

Seed, D. (2011). Science Fiction, A Very Short Introduction. New York: Oxford University.

Tyldum, M. (Yönetmen). (2016). Passengers [Film].

Vejar M. vd. (1994-98). Babylon 5 [Dizi].

Wachowski Kardeşler, (Yönetmen). (1999, 2003). Matrix [Film].

Zizek, S. (2011). İdeolojinin Yüce Nesnesi. (Dördüncü Basım). (T. Birkan, Çev.). İstanbul: Metis. 